\title{
LOGISTICS PLATFORMS - TRENDS AND CHALLENGES
}

\author{
Maria Alejandra Acevedo Cote \\ Faculty of Engineering, Universidad Distrital Francisco José de Caldas, Kr 11 \# 148-59 Cedritos Capri Bogotá, \\ Colombia, maacevedoc@ correo.udistrital.edu.co (corresponding author) \\ Daniela Fernanda Sánchez Polanco \\ Faculty of Engineering, Universidad Distrital Francisco José de Caldas, Kr 113F \# 63J-32 Sabanas del dorado Bogotá, \\ Colombia,dfsanchezp@correo.udistrital.edu.co \\ Javier Arturo Orjuela-Castro \\ Faculty of Engineering, Universidad Distrital Francisco José de Caldas, Kr 71D \# 75A-22 Bonanza Bogotá, Colombia, \\ jorjuela@udistrital.edu.co
}

Keywords: logistics platforms, typologies, concepts

Abstract: Logistics platforms (LP) are business models developed to improve the performance of all logistics activities of a supply chain (SC). About logistics platforms, the scientific literature details the management, implementation, importance, typologies, comparisons with international platforms, as well as cited case studies therein. The literature also highlights many trends of the adoption of technology as well as challenges resulting from the rapid evolution of said technology. We present a discussion of an LP, as well as an LP's importance to its SC. We discuss eight types of LPs, their applications, and their associated implementation phases. This important volume of articles that we summarize seeks to solve complex problems with mathematical formulations. The literature potentiates the processes carried out in LPs by means of case-study analyses through comparing some LPs of South America against the more technological-based and automation-based LPs of Europe, of Southeast Asia, and of North America. The studies of LPs in global SCs, and enclosed cycle SCs, have shown that there are many challenges stemming from global climate change, which places uncertainty in the process of estimating stochastic parameters in the new global market. This would mandate strengthening the methodologies of Hub- and Cross-docking and understanding trends, such as the need to fortify the management of LPs by utilizing information technologies and communication technologies and updating local markets to make global markets more resilient in the face of pending environmental shifts.

\section{Introduction}

Logistics generates a competitive advantage from the optimized management of material flows and the efficient use of resources in supply chains (SC). In recent decades, logistics platforms (LP) have become a fundamental resource for logistics management in SC and contribute to the balance between supply and demand by regulating material flows between the different factors in a SC [1]. Given the importance and proliferation of different types of platforms in many countries and economies globally, it is vital to establish some fundamental concepts about LPs, their management forms, typology, and a comparative analysis between various LPs from around the world.

This article presents a literature review of LPs. We show our research methods in the following section. We present a corresponding literature review of logistics platforms, which unpacks the importance, management, implementation, typologies, comparison of national and international platforms and analyses of case studies. This article concludes with further research recommendations.

\section{Literature review methodology}

For the development of this article, we present a systematic literature review based on what was proposed in [2]. Initially, we asked some guiding questions in order to structure this review. We asked the following: What is a logistics platform? How are they managed and implemented in Colombia and around the world? Why are logistics platforms important? How do they function? What are some advantages and disadvantages of logistics platforms? After asking ourselves these questions, we followed in stages: Protocol and search strategy, review and selection criteria, data extraction, data synthesis and report.

The exhaustive search in the databases produced a total of 56 documents, with the protocol shown in Table 1.

Figure 1, shows the trend of publications over the years and it is evident that the year with the highest number of publications is 2013 with 16 documents. This graph was made from articles reviewed in databases such as Scopus with 29, Science Direct with 27, Google Scholar with 24, Web of Science 20, Springer Link 10 and 8 in IEEE.

Based on the information consulted in the aforementioned databases, the countries with the highest number of publications were identified as China, Brazil, Iran and the United States (see Figure 2).

Figure 3. The results show the formation of 33 clusters using the VOSviewer tool based on the keyword grouping criterion. It also presents an evolution of how the literature presented each topic through time. 


\begin{tabular}{|c|c|c|}
\hline Stages & Order of Activities & Results \\
\hline \multirow{5}{*}{ Search strategy } & $\begin{array}{l}\text { Search in Web of Science, Science Direct, Springer Link, IEEE, } \\
\text { Scopus and Google Scholar databases. }\end{array}$ & \multirow{5}{*}{$\begin{array}{l}\text { We found (118) articles, } \\
\text { of which (62) were } \\
\text { discarded according to the } \\
\text { exclusion terms. Thus, } \\
\text { (56) viable articles were } \\
\text { published between the } \\
\text { years } 2002 \text { and } 2021 \text {, } \\
\text { which demonstrates the } \\
\text { relevance and timeliness } \\
\text { of the topic. }\end{array}$} \\
\hline & $\begin{array}{l}\text { Search with the search terms: "LOGISTICS PLATFORM" and } \\
\text { "PLATAFORMAS LOGISTICAS" }\end{array}$ & \\
\hline & $\begin{array}{l}\text { Six specific subtopics are established: concept, importance, } \\
\text { management, typologies, comparison with international } \\
\text { platforms and analysis of case studies. }\end{array}$ & \\
\hline & $\begin{array}{l}\text { Spreadsheet tabulation, used for item categorization and data } \\
\text { analysis. }\end{array}$ & \\
\hline & $\begin{array}{l}\text { Research on the implementation of LPs and comparison of the } \\
\text { same with respect to Colombia and other countries. }\end{array}$ & \\
\hline \multirow{2}{*}{$\begin{array}{l}\text { Review and } \\
\text { selection criteria }\end{array}$} & $\begin{array}{l}\text { Selection criteria: review articles and in applications, those with } \\
\text { the most citations with keywords in the title. Articles related to } \\
\text { chemical studies, medicine, computer science, E-commerce and } \\
\text { digital platform content are excluded. }\end{array}$ & \multirow{2}{*}{$\begin{array}{l}\text { Of the (56) articles } \\
\text { selected, (15) are } \\
\text { empirical and (41) are } \\
\text { theoretical. }\end{array}$} \\
\hline & $\begin{array}{l}\text { General reading of each article to identify whether it is } \\
\text { theoretical (based on theories) or empirical (with an applied } \\
\text { study) and discard those that do not meet the selection criteria. }\end{array}$ & \\
\hline \multirow{3}{*}{ Data extraction } & $\begin{array}{l}\text { Completion of the reference list for the one hundred and four } \\
\text { articles, with general data of the article such as: objective, } \\
\text { source, problem, methodology, results, contributions, and } \\
\text { number of citations. }\end{array}$ & \multirow{3}{*}{$\begin{array}{l}\text { Review of } 56 \text { documents } \\
\text { for the conceptual } \\
\text { framework. }\end{array}$} \\
\hline & $\begin{array}{l}\text { Specific forms are filled out to extract the relevant information } \\
\text { regarding the } 6 \text { established subtopics. }\end{array}$ & \\
\hline & $\begin{array}{l}\text { Review of articles and analysis of the same in the established } \\
\text { formats. }\end{array}$ & \\
\hline \multirow{3}{*}{$\begin{array}{l}\text { Data synthesis and } \\
\text { report }\end{array}$} & $\begin{array}{l}\text { Each of the authors' contributions was analyzed in the defined } \\
\text { subtopics. }\end{array}$ & \multirow{3}{*}{$\begin{array}{l}\text { A conceptual and } \\
\text { theoretical framework } \\
\text { related to logistics } \\
\text { platforms is generated. }\end{array}$} \\
\hline & $\begin{array}{l}\text { A compilation of information on the seven subtopics established } \\
\text { for logistics platforms was carried out. }\end{array}$ & \\
\hline & $\begin{array}{l}\text { Comparative tables were prepared for the status of information } \\
\text { on logistics platforms in the international environment with } \\
\text { respect to the article "Operators and logistics platforms" [3]. }\end{array}$ & \\
\hline
\end{tabular}

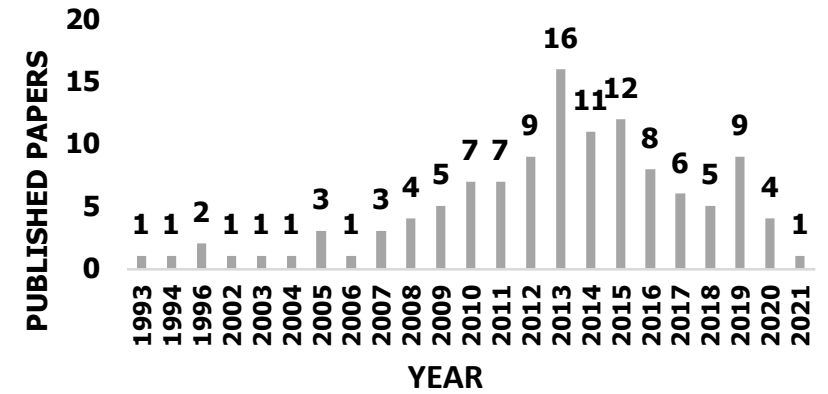

Figure 1 Year of publication of articles reviewed for logistics platforms

In 2010, the topics discussed are supply chain management (with a frequency of 10), in mid-2012 logistics (with a frequency of 18), logistics platforms (with a frequency of 11), in 2013 concepts such as hub location (with a frequency of 10) and intermodal transport (with a fre-quency of 5), in 2016, logistics platforms such as crossdocking (with a frequency of 4), and freight transport (with a frequency of 2) and case studies related to this topic (with a frequency of 3). In 2018 the environmental perspective appears in the LP finding words such as green initiatives.

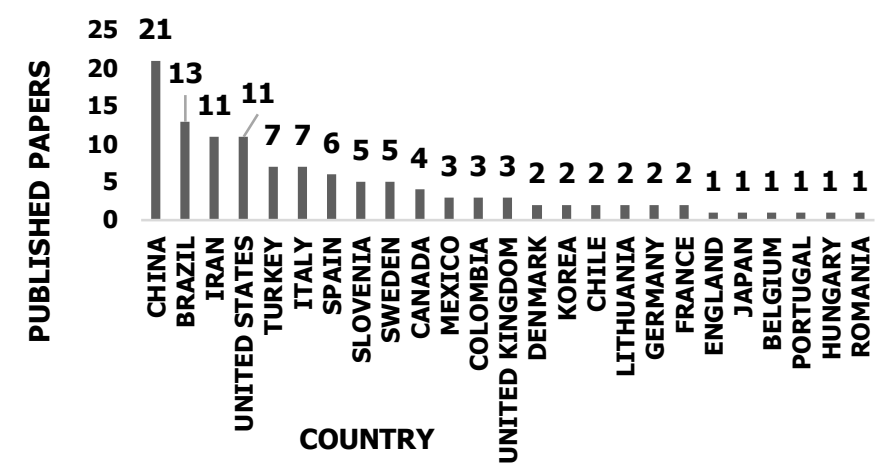

Figure 2 Place of origin of the articles reviewed for logistics platforms 


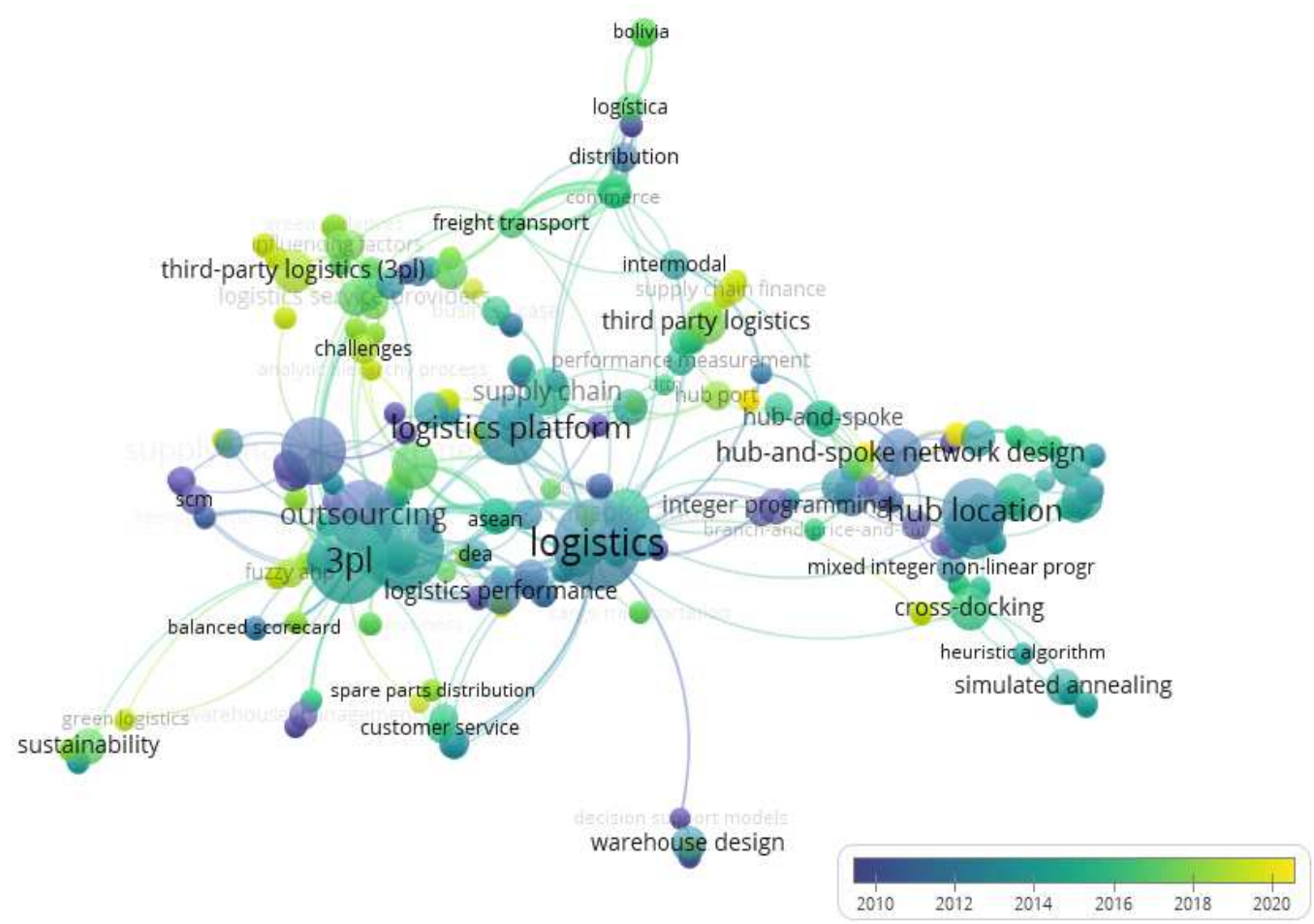

Figure 3 Elaborated in the tool VOSviewer, Bibliometric networks by year of publication and keywords for LP

\section{Result and discussion}

Based on the literature we reviewed, under the criteria of our methodology, we present the results. We initially look for the concept of LP, followed by: importance, management, typology, comparison, and analysis of case studies of logistics platforms.

\subsection{Logistics platform: history and definition}

The concept of the logistics platform is not a recent one, thus many unique definitions exist, though many share common themes and vocabulary. We emphasize that there is no common agreement on exactly what logistics platforms are. Many authors have used the term in a wide diversity of contexts. There is discrepancy in research and in the literature [4]. The first definition emerged in France in the 1960s as a result of the development of management operations studies [5,6]. Later, other names appeared such as: plateformes logistiques publiques (public logistics platforms), distriport, distripark, interport, freight village, integrated freight centers, logistics park [5-8], logistics center, distribution center, central warehouse, freight/transport terminal, transport node and logistics depot $[9,10]$. Table 2 compiles the myriad definitions.

Table 2 Logistics Platform Definitions

According to (EUROPLATFORMS) 1997 "It is a delimited area within which the activities related to the transport, packaging and distribution, for national and/or international transit of goods of one or several operators are carried out" $[3,6,8,11-15]$.

According to Abrahamsson, Aldin, and Stahre 2003 "A logistics platform is a homogeneous part of the logistics system, which an organization manages and controls centrally, a resource base for new market positions. The LP includes logistics operations, a physical structure, processes, activities and information systems" [5,13,15-19].

"A logistics platform is defined as a strategically located site, performing various logistics activities, with a large transportation infrastructure that provides competitive advantages and improves the logistics operations of the participants involved in the companies' business" [6].

Dubke (2006) states that LP allows the: "Coordination of the network of all logistics services, providing greater competitiveness through lower costs of management and operation of the logistics chain" [13].

Carvalho et al (2010), state that the LP: "is where different supply chain actors can integrate in the same physical location, assisting logistics flows and acting as a strategic interface between global and regional networks with the objective of improving SC efficiency"[13,15].

Antúna \& Alarcón (2014), define it as a specialized area with the necessary infrastructure and services for co-modal transportation, which adds value to the products that use it $[13,15,19]$. 
LOGISTICS PLATFORMS - TRENDS AND CHALLENGES

Maria Alejandra Acevedo Cote; Daniela Fernanda Sánchez Polanco; Javier Arturo Orjuela-Castro

LPs provide a complex service to communicate and evaluate relevant information that affects the performance of SCs [13$15]$.

The LP is a specific place where activities related to transportation, logistics and distribution of goods are carried out, uses the same basic services to the different actors involved and achieves greater efficiency in its operations [14].

An LP is the place where it supplies transport and storage infrastructure areas, improving the competitiveness of companies, by de-bureaucratizing and speeding up business operations through efficient logistics operations [20].

LP is a flattened organizational structure that connects more than one logistics agency. It designs negotiation mechanisms to improve network effects. It decreases information asymmetry between industries, improves operational efficiency and saves operating costs [21].

LPs show a special configuration where a large group of companies can be found in a limited geographical area; in these areas, there is a breakdown of transportation chains, as well as other activities such as consolidation, deconsolidation and warehousing of cargo. The LP share several services, transportation areas and resources that allow the execution of activities related to distribution, transit of goods and associated costs [22].

LPs are distribution components where goods are trans-shipped, stored, marketed in bulk, packed, sorted and grouped for shipment to beneficiaries [23].

The LP is an area of logistics services, whether delimited in the territory or not, located at a point in the transport or logistics chains, contributing to the value chain by providing services to the transport and telecommunications network, stakeholders (users, operators and customers), vehicles and equipment [14,24].

A logistics park refers to the physical location of logistics facilities, where there are several logistics companies to conduct business. It is established to concentrate logistics facilities and conduct collective logistics operations, or the rational distribution of space of urban facilities [25].

In summary, a logistics platform, of any type, can be considered as a source of resources for the implementation of logistics processes in a predefined environment, offering customized infrastructure, a developed information communication system, logistics technology, specialized logistics workforce, and favorable support at the highest level [10].

A logistics platform can be defined as a physical management and control space, where general and specialized logistics processes such as loading, unloading of goods, shipments, storage, packaging, unpacking and transship-ment are carried out. It provides competitive advantage to stakeholders by coordinating operations, through the collaboration of logistics agents, integrating the use of resources, and achieving efficiencies by reducing associated logistics costs.

\subsection{Importance of logistics platforms}

- The relevance of logistics platforms, as internally coupled systems linked to a complex system of interrelationships, derives from the functions and services they offer. Among the services provided in the LP, some are shown [26]:Territorial planning, promotion and intermodal development with routing and traceability analysis.

- Scheduling and management of plant equipment and real estate.

- Logistics services for warehousing, handling of goods, management of shipping and receiving of goods, planning of transportation services, and coordination of routing and traceability.

Coordination of intermodal terminals in the management of shipment, reception and maintenance of containers, commercialization of freight transport by rail
services.By having these services and functions in the same physical location, transportation cycle time is reduced and customer service is improved, therefore generating competitive advantage [27]. There are different benefits with a logistics platform. The most important is to make its region of influence more logistically friendly. It offers benefits to companies by providing greater flexibility, responsiveness, sustainability to distribution activities, effective logistics adaptation to changes in advertising and sales tactics, timely business expansion to new markets, and reduction in logistics costs. Regarding the supply chain, LP is important in the standardization of logistics processes, lower costs, faster material flow, less operational work and the integration of new partners [28]. Some authors claim that logistics platforms decrease negative environmental impacts by increasing collaboration between transportation systems, reducing carbon dioxide emissions, and shortening the distances traveled by delivery vehicles [6].

Some advantages of LPs are [23]:

- Upstream, they provide advanced inventory management, quality control, mass customization of inprocess products, assembly operations, flow coordination and optimization, reliable logistics processes, and just-intime deliveries on production lines.

- - Downstream, they can map the distribution of finished products with distribution platform management, preorder unit, packaging or customization collaboration, quality control, presentation media coordination, and sales promotion strategies. 


\subsection{Management of logistics platforms}

This section presents the implementation phases and forms of LP management found in the literature, Marques de Souza et al. [20] establishes the implementation phases, Figure 4.

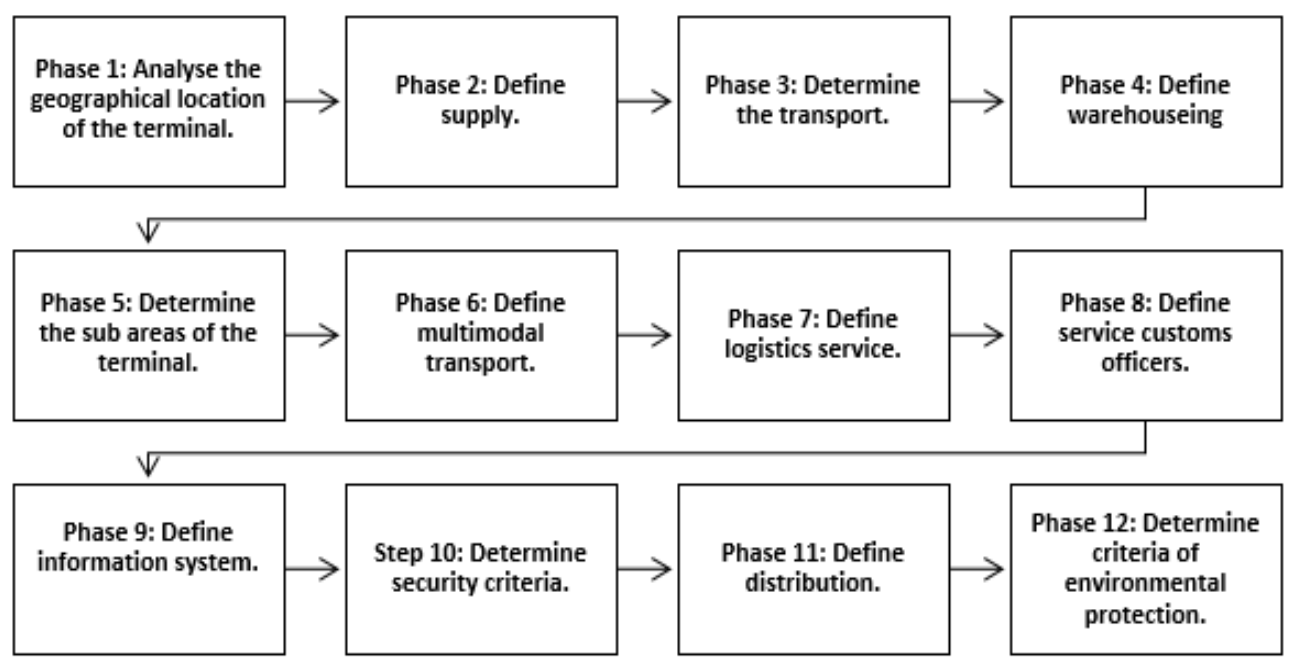

Figure 4 Implementation phases of a logistics platform Source. Elaborated from [20]

Marques de Souza et al. [20] determine as activities within each of the phases the following: (1) the location of the region, intermodal connections, and logistics needs are identified, (2) where suppliers are, how they are categorized, and their needs are identified, (3) define the appropriate mode for the terminal that is related to the logistics network activities, and it is stipulated whether the transport is of the logistics company or of third party, (4) operationally define the shipment criteria at the terminal, allowing the exchange of data on the shipment as well as specific needs and type of storage, (5) define the transport, logistics user, and general service sub-units, (6) determine the multimodal user, transport, and actions in the logistics network, (7) identify and establish the logistics user and specific activities in the logistics network, (8) determine the areas and customs authorities, (9) isolate each activity in the logistics network, (10) define the security criteria used, (11) define how the nature of distribution is identified, strategies are configured, physical distribution management is carried out, and the needs in the logistics network, (12) determine the economic stages of resources, and analyze waste management plans and environmental protection for the physical area of, and surrounding, the terminal.

Because of their broad definitions, both LP management and SC management come into being in many different forms. A few examples are listed below:

- AS SUPPORT FOR MARKETING STRATEGY: In SC management, an LP is a homogeneous, controlled and designed part of the logistics system. It is the basis for new marketing channels. Logistics platforms do not evolve independently. They are affected by the marketing channel strategy and must support the business strategy. The logistics platform must be flexible in the short term to offer operational opportunities and in the long term to apply to new marketing channels. Centralizing logistics with an LP increases proximity to marketing strategy and market channels [29].

- THROUGH AN ARCHITECTURE: The context of the logistics platform is composed of three elements: the network of members, marketing and the structure of the logistics module, to design and establish an adequate infrastructure and provide logistics services supported by information technologies [30].

\section{- THROUGH INFORMATION AND} COMMUNICATION TECHNOLOGIES: A logistics platform must evaluate and communicate information that can have an effect on the flow of materials. The LP provides specific means and rules to manage interactions and links basic planning functions of various levels of aggregation in companies and their SC, through information and communication technologies with privacy and security to partners [31].

- THROUGH VALUE CREATION: Logistics platforms create value through reduced costs, customized service options, greater operational efficiency, and higher quality services. Advantages have been identified in collective logistics platforms, such as resource matching, route planning, driver monitoring, matching, routing, tracking, driver selection, feedback, and online payments [32]. 
ECLAC, in the 2015 Logistics Guide, proposes four management models for the development of logistics platforms [33]:

- Fully Public: The state is in charge of the construction and operation of the logistics platform, operating through companies contracted with public financing and risk, and they promote a balanced economic and territorial expansion. They promote and improve key logistics corridors for the country and the development of logistics platforms with the objective of favouring the competitiveness of small and medium-sized entrepreneurs, facilitating border trade and reducing logistics costs.

- Public-Private Partnership: Public-private arrangement that seeks a specialized company as logistics operator, delegates the execution of the logistics participation to the private sector, but without releasing the control of state-led economic and commercial development, which would be administered through government supervision in strategic decisions during the execution phase. It is formalized by and restrained by public law.

- Concession: The construction and operation of the LP is entrusted to the private sector by transferring the risks. The public sector provides land and controls the fees to be charged. Monitoring is limited to the provisions of the concession contract, and execution is left to the private sector.

- Totally Private: The purchase of land, design, investment, and operation is totally private, and there is no state intervention, or it is limited to granting tax incentives. It responds to the needs of industrial or commercial companies with problems of regulation and competition between the State and regional or local authorities.

\subsection{Typologies of logistics platforms}

In the literature review, eight classes of logistics platforms are found according to their operational complexity and operational integration [34], which are summarized in Table 3.

Table 3 Types of Logistics Platforms DESCRIPTION

\section{APPLICATION}

Facilities are responsible for managing transportation and

Distribution

Logistics

Platforms -

PLADIS logistics in distribution and linking cross-border supply chains. There are three types of distribution logistics platforms (PLADIS): metropolitan, regional, and international. These, in turn, are related to the physical distribution of goods that articulates transportation and urban operations and the location of distribution centres.

- Urban, regional, and megalopolis cargo distribution.

- For companies that produce and commercialize consumer goods.

- To provide facilities to carriers.

- For interchange of locomotives and personnel, as well as the transfer of cargo from one vehicle to another.

Logistics

Platforms at

Border - PLF
Support facilities for the production of transportation and logistics services near land border crossings [35].

- Inventory management, order processing and office and freight broker facilities.

- Lodging and restaurant services for drivers.

\section{Logistics \\ Platform for \\ Cluster \\ Support - \\ PLC \\ Facilities for the production of transportation and logistics services to support distribution and marketing in companies' supply chains. Logistics operators, distribution centres, reception centres, and terminals for transportation companies are generally located on these platforms.}

\section{Port Logistics \\ Activities \\ Zone - ZAL}

Facilities are responsible for receiving, handling, and distributing goods from port and catchment areas. The range of services includes real estate services for logistics operators, freight forwarders, and customs brokers, carriers, railroads, importers and exporters.
- To support the logistics supply chains of companies, industrial, and commercial distribution.

- Consolidation and deconsolidation services of maritime cargo, warehousing and/or storage, unpacking and/or labelling, packaging, palletizing, customs services.

- Logistics services (consolidation and deconsolidation, labeling, quality control, inventory control, etc.), and customs services. 
Intermodal Logistics platforms for rail interchange. Dry ports are a special Terminals Railway ITR , Dry Ports - DP category of intermodal rail terminals that are located within the territory and connected by rail to a seaport, whose port authority formally assumes a certain degree of responsibility for the operations carried out there.

- Modal interchange (rail, road and/or maritime).

- Companies sorting and packaging agricultural products such as tomatoes, avocados, citrus and berries.

- Agricultural processors of sauces, juices, thin cuts of beef, honey, and jams.

Thicultural and agro-industrial production. These platforms

Centers AGROLOG managed depending on the type of agricultural and agroindustrial production, their area of influence, and the logistic requirements of the commercialization channels.

- Trucking unions involved in the transportation of agricultural products.

- Associations of small producers.

- Cold chain logistics operators.

- Government agencies in phytosanitary control.

Also called wholesale markets, FLCs combine distribution and

Food marketing logistics and are typically located near cities in order

Logistics

Centers -

FLC to supply food to the population and market to wholesale suppliers and distributors. Commonly they must have warehouses for the collection and marketing of products, as well as parking areas for loading and unloading, and in some cases, they have auction yards. Source: based on [34].

\subsection{Comparison of logistics platforms}

Around the world, logistical processes are managed by logistics operators using logistics platforms. This section shows the description, surface area, and services provided by representative logistics platforms from Europe [36], Asia, the United States, Canada, Brazil, and Colombia [37]. These platforms were selected in order to observe the contrast between logistics platforms with high levels of automation (i.e. the United States and Canada) to those found in Colombia, which tend to have less automation.

The literature describes the particular case of nineteen logistics platforms in Europe, of which nine are in Spain (Coslada Transport Center, ZAISA, Madrid Transport Center, Vitoria Transport Center, Pamplona Transport City, Azuqueca Dry Port, Zaragoza (PLAZA), ZAL Barcelona and Bilkakobo-Aparcabisa) with surface areas between 13,117,977 $\mathrm{m}^{2}$ and $200,000 \mathrm{~m}^{2}$. There are five logistics platforms in Germany (GVZ Bremen, GVZ Hamburg, GVZ Koblenz, GVZ Rostock and Rheinhafenge Sellschaft Weil am Rhein) with surface areas between 4,720,000 $\mathrm{m}^{2}$ and 260,000 $\mathrm{m}^{2}$. There are three logistics platforms in Italy (Interporto di Novara, Ce.P.I.M.M.S.p.A. and Interporto Quadrante) with surface areas between $2,500,000 \mathrm{~m}^{2}$ and $840,000 \mathrm{~m}^{2}$. There is one logistics platform in Denmark (The Scandinavian Transport Center (Freight Village)) with a surface area of $1,300,000 \mathrm{~m}^{2}$. There is one logistic platform in Hungary (BILK Kombiterminal) with a surface area of $1,000,000$ $\mathrm{m}^{2}$. The services offered in the LPs are reception, movement, repacking, reassembly, transhipment, distribution, storage, consolidation, production, trade, assistance, loading, unloading, sorting, technical inspection for general shipments, express deliveries, permanent exhibition, vehicle sales, refrigerated chambers, and dry and liquid bulk [36].

In South Korea, there are two logistics platforms (Busan New Port Distripark and Gamcheon Distripark), each with a surface area of $3,070,000 \mathrm{~m}^{2}$, that provide manufacturing, storage, distribution, consolidation, customs clearance, packing, repacking, loading and unloading services for all shipments. Three logistics platforms are identified in the United States (Alliance Texas, Pureland and Rickenbacker) with surface areas between $180,000,000 \mathrm{~m}^{2}$ and 5,260,934 $\mathrm{m}^{2}$. There is one logistics platform in Canada (Halifax Gateway) with a surface area of $505,850 \mathrm{~m}^{2}$, and it performs activities such as receiving, manufacturing, assembly, distribution, consolidation, exchange or transhipment, loading, unloading and storage for shipments in general, refrigerated chambers, and dry and liquid bulk. To conclude the international platforms, reference is made to the case of Brazil, where there are two logistics platforms (Multimodal de Goiás in Anápolis and Multimodal Viracopos in Campinas) with a surface area of $6,967,790$ $\mathrm{m}^{2}$ and $7,000,000 \mathrm{~m}^{2}$, respectively, and they provide services of consolidation, loading, unloading, storage for 
LOGISTICS PLATFORMS - TRENDS AND CHALLENGES

Maria Alejandra Acevedo Cote; Daniela Fernanda Sánchez Polanco; Javier Arturo Orjuela-Castro

general shipping, refrigerated chambers, and dry bulk and liquids [36].
In the case of Colombian logistics platforms, the corresponding information can be seen in Table 4.

Table 4 Logistics Platforms in Colombia

\begin{tabular}{|c|c|c|c|c|c|c|c|}
\hline Type & $\begin{array}{l}\text { Logistics } \\
\text { Platform }\end{array}$ & $\begin{array}{c}\text { Extension } \\
\text { (Acres) }\end{array}$ & $\begin{array}{c}\text { Capacity } \\
\text { to mobilize } \\
\text { (ton per } \\
\text { year) }\end{array}$ & $\begin{array}{c}\text { Number } \\
\text { of } \\
\text { employee } \\
\text { s }\end{array}$ & $\begin{array}{l}\text { Type of } \\
\text { load }\end{array}$ & Services & Benefits \\
\hline \multirow{6}{*}{ 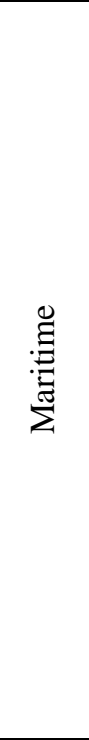 } & Chocó & 44 & 829.147 & - & Liquid bulk & \multirow{23}{*}{$\begin{array}{l}\text { Storage area, } \\
\text { general logistics } \\
\text { activities, product } \\
\text { transformation, } \\
\text { land and river } \\
\text { docks, parking, } \\
\text { delivery, receipt } \\
\text { of goods, } \\
\text { inspections, cargo } \\
\text { nationalization, } \\
\text { labeling, } \\
\text { weighing, } \\
\text { invoicing, } \\
\text { container } \\
\text { terminal, and } \\
\text { cross-docking } \\
\text { center. }\end{array}$} & \multirow{23}{*}{$\begin{array}{l}\text { Employment } \\
\text { generation, } \\
\text { optimization of } \\
\text { logistic times, } \\
\text { reduction of gas } \\
\text { emissions, } \\
\text { integral and } \\
\text { functional urban } \\
\text { development, } \\
\text { increase of } \\
\text { regional } \\
\text { income, greater } \\
\text { logistic- } \\
\text { economic } \\
\text { efficiency, } \\
\text { consolidation of } \\
\text { the international } \\
\text { market for } \\
\text { producers, } \\
\text { channeling of } \\
\text { traffic, and } \\
\text { reduction of } \\
\text { transportation } \\
\text { cost overruns. }\end{array}$} \\
\hline & Cartagena & 15 & 34.558 .932 & 989 & $\begin{array}{l}\text { Containers, } \\
\text { Bulk coal, } \\
\text { Liquid and } \\
\text { solid bulk }\end{array}$ & & \\
\hline & Barranquilla & 94 & 10.860 .562 & 378 & $\begin{array}{l}\text { Containers, } \\
\text { Bulk coal, } \\
\text { Liquid and } \\
\text { solid bulk }\end{array}$ & & \\
\hline & Santa Marta & 33.63 & 10.738 .633 & 335 & $\begin{array}{l}\text { Containers, } \\
\text { Bulk coal, } \\
\text { Liquid and } \\
\text { solid bulk }\end{array}$ & & \\
\hline & Urabá & 120.4 & 13.953 & - & Liquid bulk & & \\
\hline & Buenaventura & 1.10 & 17.383 .324 & - & $\begin{array}{l}\text { Containers, } \\
\text { Bulk coal, } \\
\text { Liquid and } \\
\text { solid bulk }\end{array}$ & & \\
\hline \multirow{11}{*}{ 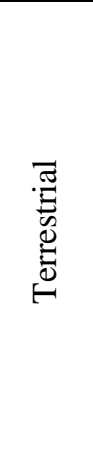 } & Eje Cafetero & 38 & 31.900 & - & \multirow{11}{*}{$\begin{array}{l}\text { Products of } \\
\text { the } \\
\text { agricultural, } \\
\text { manufacturi } \\
\text { ng, mining } \\
\text { and } \\
\text { livestock } \\
\text { sectors }\end{array}$} & & \\
\hline & Soacha & 45 & 7.555 & - & & & \\
\hline & Tocancipa & 38 & 271.648 & 1.000 & & & \\
\hline & Cúcuta & 21 & 17.522 & - & & & \\
\hline & Bogotá & 64 & 246.613 & 30.200 & & & \\
\hline & Manizales & 24 & 17.042 & - & & & \\
\hline & Buga & 70.5 & 9.640 & - & & & \\
\hline & Dibulla & 355 & 21.906 & - & & & \\
\hline & Rionegro & 46 & 110.514 & - & & & \\
\hline & Cartagena & 72.81 & 236.487 & - & & & \\
\hline & Cali & 93 & 107.526 & 17.000 & & & \\
\hline \multirow{2}{*}{ 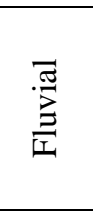 } & $\begin{array}{c}\text { Barrancaberm } \\
\text { eja }\end{array}$ & 120 & 421.038 & - & $\begin{array}{l}\text { Containers, } \\
\text { Liquid Bulk }\end{array}$ & & \\
\hline & Puerto berrio & - & 200.000 & 50 & $\begin{array}{c}\text { Bulk, } \\
\text { hydrocarbo } \\
\text { ns, minerals }\end{array}$ & & \\
\hline \multirow[b]{4}{*}{$\cdot \frac{\bar{\Xi}}{\frac{0}{2}}$} & Bogotá & 690 & 370.630 & 1.818 & \multirow{4}{*}{$\begin{array}{l}\text { Flowers, } \\
\text { vegetables, } \\
\text { fruits, } \\
\text { medicines, } \\
\text { plastics, } \\
\text { books, } \\
\text { semiprocess } \\
\text { ed products, } \\
\text { etc }\end{array}$} & & \\
\hline & Medellín & 120 & 2.088 & 6.500 & & & \\
\hline & Cali & 370.74 & 15.105 & - & & & \\
\hline & Barranquilla & 33.5 & 10.470 & - & & & \\
\hline
\end{tabular}

Source: elaborated from[37-40].

Based on the above information, it is evident that the Korea, the United States and Italy use more technology and platforms in Spain, Denmark, Germany, Hungary, South are more automated, which means that they can cover a 
larger territory in a shorter time, allowing them to handle larger volumes of merchandise and services than those in Colombia and Brazil.

\subsection{Analyses of case studies}

Several authors seek to solve problems and enhance the processes carried out in the LP by means of surveys, methods, algorithms, mathematical models, and simulations. In [41], the authors present problems related to the reception of vehicles and goods in an LP of the agrifood sector, which is solved by means of a stochastic and dynamic discrete event simulation. In [42], the authors explored the implementation of an LP where a fourthgeneration supplier (4PL) operates harvesting processes, conducted an online survey to transporters in the sector to analyze the technological, organizational, and environmental criteria they could apply to streamline productivity. In [43], the authors discovered that mathematical programming could solve delays in LP networks through the precise allocation of resources.

In [44], the authors apply governance theory in LP and derive a typology of governance relationships. While [45] and [46] propose performance indicators that can be used in management. In [47], the authors propose, through a review of the literature and a survey with a group of experts, the principles of corporate and public management. In [48], the authors analyze the environmental performance of a Belgian logistics platform, employing a multi-criteria strategy to assess how it affects stakeholders.

In [49], the authors examine the relationship between logistics park platforms, geographic location, and operational performance. In [50], the authors, with the informational support of LP, predict logistics performance, and surveys were conducted to companies in the logistics sector in China for further analysis. In [51], the authors implemented local search algorithms to create a feasible and useful schedule of LP with fluctuations in the duration of operations.

The authors in [52] seek to determine the optimal location of logistics platforms, the necessary sectors and the allocation of customers in order to minimize the costs for their stakeholders and suppliers, for which a linear integer programming model is formulated and solved with a hybrid algorithm. Finally, [53] optimizes the container loading of intermodal logistics platforms with the purpose of reducing the inventory and labour required by means of a mixed-integer linear programming model, solved with a decomposition heuristic.

\section{Challenges}

Researchers face challenges regarding the representation and study of LPs of supply chains in globalized economies, where flows of materials and/or goods occur between towns, cities, states, provinces, departments, countries, and continents. Every decision regarding-including but not limited to-the location of the LP, inventory levels, vehicle route optimization (including various links and multimodal transportation), storage and warehouse design will have cascading consequences throughout the entire LP. In this context, performance measures that promote sustainability must be evaluated, taking into account economic, environmental, and social factors [54].

It becomes necessary to explore LP design environments with modelling for efficiency analysis [55], the design of a logistics platform, and the integration of reverse flow requirements in logistics platforms to assess their performance and maturity, as well as additional direct and reverse flow features that help in optimizing the location of LPs [49].

Studies with stochastic parameters are required, which also evaluate the behaviour of Hub-docking, Crossdocking, and distribution centres with storage, with respect to the dynamics of flows in the supply chain. It is evident for the need to carry out studies that evaluate the inbound, storage, and outbound flows in the LP, the order picking and consolidation, with respect to their incidence in the design inside the LP. As well as in the layout of the areas and decisions on static and dynamic shelving [56].

The need to expand the effective management of logistics platforms with information and communication technologies is evident. Our analysis of case studies focused on determining their future capacity and performance by means of additive and/or multiplicative mathematical models, as well as Decision Making Unit (DMU) in the analysis, for the implementation of logistics platforms that add resiliency to adapt to new distribution challenges.

Logistics platforms are the future of the global economy. With them, the planning of the distribution of goods and services around the world becomes ordered and logical. Without them, the global economy would collapse, leaving only a minimum of goods and services available to small regional centres. Human beings are good at many things, but one in particular: adaptation. Logistics platforms are a brilliant example of humanity's ability to solve global problems of immense complexity, which has given humanity the ability to survive in the distant past, the ancient and historical times, and will allow civilization to flourish into the future.

\section{Conclusions}

Although the concept of logistics platform is an old one, there is no unified consensus in the research literature on what a logistics platform actually is, since authors use the term in a wide variety of contexts. However, we identified that the most commonly used definitions are those corresponding to (EUROPLATFORMS - 1997) and (Abrahamsson, Aldin, and Stahre - 2003), in which a LP is understood as a delimited area where logistics operations management and control activities are performed, also several proposals are identified for the implementation of a logistics platform and eight types of logistics platforms. 
There are similarities and differences between the LPs in Europe, Asia, Brazil, and Colombia with respect to the operation, size and services they provide. The platforms in Spain, Denmark, Italy, Germany, Hungary, South Korea, and the United States are more technologically advanced and are more automated, and therefore cover a broader area of territory, which allows them to handle larger volumes and with a higher turnover of goods than those in Colombia and Brazil.

Finally, the literature identifies a large number of articles that seek to solve problems and enhance the processes carried out in the LPs by means of case study analyses in which tools such as surveys, methods, algorithms, mathematical models, and simulations are used.

\section{References}

[1] ORJUELA, J.A.: Impact of food supply chain design on the balance of logistic flows, pp. 28-63, 2018, [Online], Available: http://bdigital.unal.edu.co/69976/ [29. Jun 2021], 2018. (Original in Spanish)

[2] RINCÓN, D.L., FONSECA, J.E., ORJUELA, J.A.: Towards a Common Conceptual Framework on Traceability in the Food Supply Chain, Engineering Journal, Vol. 22, No. 2, pp. 161-189, 2017. doi:10.14483/udistrital.jour.reving.2017.2.a01 (Original in Spanish)

[3] ORJUElA, J.A, CASTRO, O. F, SUSPES, E. A.: Operators and logistics platforms, Tecnura, Vol. 8, No. 16, pp. 115-127, 2005. doi:10.14483/22487638.6249 (Original in Spanish)

[4] LIPIČNIK, M., GAJŠEK, B., ŠIMENC, M.: The logistics platform disambiguation, Research in Logistics \& Production, Vol. 2, No. 1, pp. 69-80, 2012.

[5] CARVALHO, C., CARVALHO, M., LIMA JÚNIOR, O.: Efficient logistic platform design: the case of Campinas plataform, in XVI ICIEOM - International Conference on Industrial Engineering and Operations Management, São Carlos, Brasil, 2010, pp. 1-11, 2010.

[6] LIMA, O.F. Jr., RUTKOWSKI, E.W., DE CARVALHO, C.C., LIMA, J.C.F.: Sustainable Logistics Platform in a Regional Brazilian Airport, International Journal of Sustainable Development and Planning, Vol. 5, No. 2, pp. 163-174, 2010. doi:10.2495/SDP-V5-N2-163-174

[7] GAJŠEK, B., GRZYBOWSKA, K.: A cross-county contextual comparison of the understanding of the term logistics platform in practice, Research in Logistics \& Production., Vol. 3, No. 2, pp. 85-108, 2013.

[8] MEIDUTE், I.: Comparative analysis of the definitions of logistics centres, Transport, Vol. 20, No. 3, pp. 106110, 2005. doi:10.1080/16484142.2005.9638005

[9] GRUNDEY, D., RIMIENĖ, K.: Logistics centre concept through evolution and definition, Engineering Economics, Vol. 54, No. 4, pp. 87-95, 2007.

[10] GAJŠEK, B., ROSI, B.: Stakeholder differences in the understanding of inter-organizational concept content as a risk factor: The case for a logistics platform, International Journal of Logistics Management, Vol. 26, No. 1, pp. 107-127, 2015. doi:10.1108/IJLM-062012-0040

[11] VARELLA, L., GONÇALVES, M.B.: Information technology as the main competence in the design of the strategic planning of logistics platforms, Journal of Technology Management and Innovation, Vol. 8, No. 3, pp. 160-172, 2013. doi:10.4067/s071827242013000400015

[12] LEAL, E., PEREZ, G.: Logistic platforms: conceptual elements and the role of the public sector, FAL Bulletin., Vol. 2009, No. 274, pp. 1-9, 2009.

[13] GAN, W., FU, C., CHEN, Z., ZHONG, R.: Research on Logistics Platform Resource Integration Based on UTAUT Model, Springer, Singapore, 2019.

[14] DA SILVA, R., PEREIRA SENNA, E., SANTOS SENNA, L., LIMA Jr., O.: Governance in logistics platforms R.M., in $22^{\text {nd }}$ International Conference on Production Research, ICPR 2013, Iguassu Falls, Brazil, pp. 137-148, 2021.

[15] ALMOTAIRI, B.: Integrated Logistics Platform, Ph.D, Chalmers University of Technology, 2021.

[16] ABRAHAMSSON, M., ALDIN, N., STAHRE, F.: Logistics platforms for improved strategic flexibility, International Journal of Logistics Research and Applications, Vol. 6, No. 3, pp. 85-106, 2003. doi:10.1080/1367556031000123061

[17] ROSO, V., ANDERSSON, D.: Encyclopedia of Maritime and Offshore Engineering, $17^{\text {th }}$ ed. Gothenburg, Sweden 1: John Wiley \& Sons, Ltd, 2017.

[18] DA SILVA, R.M., SENNA, E.T.P., LIMA, O.F. Jr., DOS S. SENNA, L.A.: A framework of performance indicators used in the governance of logistics platforms: the multiple-case study, Journal of Transport Literature, Vol. 9, No. 1, pp. 5-9, 2015. doi:10.1590/2238-1031.jtl.v9n1a1

[19] GRZYBOWSKA, K., GAJŠEK, B.: Supply Chain Logistics Platform as a Supply Chain Coordination Support, in PAAMS 2016: $14^{\text {th }}$ International Conference on Practical Applications of Agents and Multiagent Systems, Seville (Spain), pp. 61-72, 2021.

[20] MARQUES DE SOUZA, F., DA SILVA COSTA., W., GOBBO JÚNIOR, J.: Logistic platforms: proposal of an implantation methodology, in POMS $18^{\text {th }}$ Annual Conference of the Production and Operations Management Society, Dallas, Texas, U.S.A, pp. 1689-1699, 2007.

[21] LINGLI, J.: Smart city, Smart transportation Recommendations of the logistics platform construction, in TY 2015 International Conference on Intelligent Transportation, Big Data \& Smart City Smart, Halong Bay, Vietnam, pp. 729-732, 2015.

[22] GARZON, M., MENDEZ, G.: Improving Service of Access on a Logistics Platform, in Proceedings of the 
2010 Spring Simulation Multiconference, Orlando, Florida, USA, pp. 1-7, 2021.

[23] LOREDANA, L., CONSTANTIN, C.: The role and the importance of the logistics platform in the intern and international transport, Annals of the Constantin Brâncuşi” din Târgu Jiu, Ser. Econ., Vol. 2011, No. 3, pp. 205-209, 2011.

[24] COSTA, B., NASSI, C. D., RIBEIRO, G. M.: A Methodology for Location of Logistics Platforms Using Geographic Information Systems, Journal of Traffic and Logistics Engineering, Vol. 1, No. 2, pp. 104-110, 2013. doi:10.12720/jtle.1.2.104-110

[25] CHEN, P.: Development of Logistics Parks in China, in Contemporary Logistics in China: Transformation and Revitalization, Z. Jiao, B. Liu, S. Lee and J. Xiao, Ed. China: Springer Nature Singapore Pte Ltd., 2017.

[26] CANONICO, P., DE NITO, E., MANGIA, G., MARTINEZ, M.: Interorganizational relationships in italian logistic platforms: the role of meta-logistic operators, in $15^{\text {th }}$ International Annual European Operations Management Association Conference (EUROMA), Groningen, Netherlands, 2008.

[27] CAMBRA-FIERRO, J., RUIZ-BENITEZ, R.: Advantages of intermodal logistics platforms: Insights from a Spanish platform, Supply Chain Management., Vol. 14, No. 6, pp. 418-421, 2009. doi:10.1108/13598540910995183

[28] GAJŠEK, B., KOVAČ, J., HAZEN, B.T.: An Organizational Framework for Logistic Platform and its Subtypes in a Search for More Logistically Attractive Regions, Organizacija, Vol. 51, No. 1, pp. 20-34, 2018. doi:10.2478/orga-2018-0002

[29] ALDIN, N., STAHRE, F.: Electronic commerce, marketing channels and logistics platforms - A wholesaler perspective, European Journal of Operational Research, Vol. 144, No. 2, pp. 270-279, 2003. doi:10.1016/S0377-2217(02)00393-4

[30] ZHANG, Z., SHI, N.: A Framework for a Logistics Platform Including Forward and Reverse Logistics, in 2010 The $2^{\text {nd }}$ IEEE International Conference on Information management and engineering, Chengdu, Sichuan, China, pp. 361-365, 2010.

[31] VÁNCZA, J., EGRI, P., KARNOK, D.: Planning in concert: A logistics platform for production networks, International Journal of Computer Integrated Manufacturing., Vol. 23, No. 4, pp. 297307, 2010. doi:10.1080/09511921003630092

[32] LI, S., WU, W., XIA, Y., ZHANG, M., WANG, S., DOUGLAS, M. A.: How do crowd logistics platforms create value? An exploratory case study from China, International Journal of Logistics Research and Applications, Vol. 22, No. 5, pp. 501518, 2019. doi:10.1080/13675567.2019.1628929

[33] INTER-AMERICAN DEVELOPMENT BANK, LOGISTICS GUIDE. Conceptual and practical aspects of freight logistics, Inter-American Development Bank, 2015. (Original in Spanish)
[34] ANTÚN, J., ALARCÓN, R.: Ranking projects of Logistics Platforms A methodology based on the ELECTRE multi-criteria approach, in XI Congreso de Ingeniería del Transporte (CIT 2014), Santander, Cantabria, pp. 5-14, 2014.

[35] ANTÚN, J., ALARCÓN, R.: Bases for feasibility analysis of Logistics Platforms at borders, in Panam 2014 Programa, XVIII Congreso Panamericano de Ingeniería del Tránsito, Transporte y Logística, Santander, Cantabria, España, pp. 6-14, 2014.

[36] MAMEDE, B.M., OLIVEIRA, G.A., MACHADO, R.L.: Multimodal logistic platforms structure analysis worldwide: a comparative study between Brazilian and foreign projects, Brazilian Journal of Operations \& Production Management, Vol. 14, No. 3, pp. 288295, 2017. doi:10.14488/bjopm.2017.v14.n3.a2

[37] MINISTRY OF TRANSPORT: NATIONAL LOGISTICS SYSTEM: A strategy for competitiveness, Bogotá, Colombia, 2018. (Original in Spanish)

[38] National Planning Department: CONPES 3547 National Logistics Policy, Bogotá, Colombia, 2008. (Original in Spanish)

[39] SUPERINTENDENCY OF INDUSTRY AND COMMERCE: Sectoral Economic Studies, An Overview of the Ports Sector in Colombia, Bogotá, 2016. (Original in Spanish)

[40] SUPERINTENDENCY OF INDUSTRY AND COMMERCE.: Colombian Airports (2010 - 2012) Market research, SUPERINTENDENCY OF INDUSTRY AND COMMERCE, Bogotá, 2012. (Original in Spanish)

[41] GATTUSO, D., CASSONE, G., PELliCANÒ, D.: A micro-simulation model for performance evaluation of a logistics platform, in $17^{\text {th }}$ Meeting of the EURO Working Group on Transportation, Sevilla, Spain, pp. 574-583, 2014.

[42] MEHMANN, J., TEUTEBERG, F., FREYE, D.: Requirements on a 4PL-Platform in After-Crop Logistics, in EFITA-WCCA-CIGR Conference Sustainable Agriculture through ICT Innovation, Turin, Italy, pp. 1-8, 2013.

[43] DELL'OLMO, P., LULLI, G.: Planning activities in a network of logistic platforms with shared resources, Annals of Operations Research, Vol. 129, No. 1-4, pp. 155-169, 2004. doi:10.1023/B:ANOR.0000030686.79587.60

[44] MONIOS, J.: Identifying Governance Relationships Between Intermodal Terminals and Logistics Platforms, Transport Reviews, Vol. 35, No. 6, pp. 767-791, 2015. doi:10.1080/01441647.2015.1053103

[45] SILVA, R.M., SENNA, E.T.P., SENNA, L.A.S.: Governance of logistics platforms: The use of a survey for building a framework of performance indicators, African Journal of Business Management, 
Vol. 8, No. 10, pp. 350-365, 2014. doi:10.5897/AJBM2014.7360

[46] MOZART DA SILVA, R., PEREIRA SENNA, E., FONTES LIMA Jr., O., DOS SANTOS SENNA, L.: Performance indicators used in the governance of logistics platforms, in XVIII Congreso Panamericano de Ingeniería de Tránsito y Transporte y Logística (PANAM), Cantabria, España, pp. 265-282, 2014.

[47] MOZART DA SILVA, R., PEREIRA SENNA, E., FONTES LIMA Jr., O., DOS SANTOS SENNA, L.: A survey on the governance principles used in logistics platforms, Journal of Transport Literature, Vol. 7, No. 3, pp. 240-269, 2013.

[48] BULDEO RAI, H., VERLINDE, S., MACHARIS, C.: Shipping outside the box. Environmental impact and stakeholder analysis of a crowd logistics platform in Belgium, Journal of Cleaner Production, Vol. 202, pp. 806-816, 2018. doi:10.1016/j.jclepro.2018.08.210

[49] LYU, G., CHEN, L., HUO, B.: The impact of logistics platforms and location on logistics resource integration and operational performance, International Journal of Logistics Management, Vol. 30, No. 2, pp. 549-568, 2019. doi:10.1108/IJLM-022018-0048

[50] ZHANG, M., XIA, Y., LI, S., WU, W., WANG, S.: Crowd logistics platform's informative support to logistics performance: Scale development and empirical examination, Sustainability, Vol. 11, No. 2, pp. 1-19, 2019. doi:10.3390/su11020451

[51] GHIRARDI, M., PERBOLI, G., SASIA, D.: Maximizing the Throughput of Multimodal Logistic Platforms by Simulation-Optimization: The Duferco Case Study, in 2011 IEEE International Conference on Automation Science and Engineering, Trieste, Italy, pp. 52-57, 2021.

[52] TANG, J., TANG, L., WANG, X.: Solution method for the location planning problem of logistics park with variable capacity, Computers and Operations Research., Vol. 40, No. 1, pp. 406-417, 2013. doi:10.1016/j.cor.2012.07.011

[53] COINDREAU, M. A., GALLAY, O., ZUFFEREY, N., LAPORTE, G.: Integrating workload smoothing and inventory reduction in three intermodal logistics platforms of a European car manufacturer, Computers and Operations Research, Vol. 112, No. December, pp. 1-10, 2019. doi:10.1016/j.cor.2019.104762

[54] GAMBOA BERNAL, J.P., ORJUELA CASTRO, J.A., MORENO MANTILLA, C.E.: The Sustainable Supply Chain: Concepts, Optimization and Simulation Models, and Trends, Engineering Journal, Vol. 25, No. 3, pp. 355-377, 2020. doi:10.14483/23448393.16926

[55] YANCHANG, L., MIN, D.: Discussion of cross docking design in modern logistics systems, in WRI World Congress on Computer Science and Information Engineering, CSIE 2009, Washington, DC United States, pp. 149-151, 2009.

[56] DEMIRTAS, N., TUZKAYA, U.: Strategic Planning of Layout of the Distribution Center: An Approach for Fruits and Vegetables Hall, in $8^{\text {th }}$ International Strategic Management Conference, Barcelona, Spain, pp. 159-168, 2012.

\section{Review process}

Single-blind peer review process. 